\title{
Growth potential and predation risk drive ontogenetic shifts among nursery habitats in a coral reef fish
}

\author{
Monique G. G. Grol ${ }^{1}$, Andrew L. Rypel ${ }^{2}$, Ivan Nagelkerken ${ }^{1,3, *}$ \\ ${ }^{1}$ Radboud University Nijmegen, Institute for Water and Wetland Research, \\ Department of Animal Ecology and Ecophysiology, PO Box 9010, 6500 GL Nijmegen, The Netherlands \\ ${ }^{2}$ Department of Fish and Wildlife Conservation, Virginia Tech, 100 Cheatham Hall, Blacksburg, Virginia 24061, USA \\ ${ }^{3}$ Southern Seas Ecology Laboratories, School of Earth and Environmental Sciences, DX 650 418, The University of Adelaide, \\ Adelaide, South Australia 5005, Australia
}

\begin{abstract}
Various species of aquatic animals have complex life cycles and utilize different habitats during consecutive phases of their life cycles. For example, many marine fish species occupy different habitat types during juvenile and adult life stages. Juveniles of some species recruit to inshore nursery habitats such as mangroves and seagrass beds, whereas large adults tend to dominate coral reefs. The mechanisms underlying apparent cross-habitat distribution patterns by life stage remain uncertain for many species. Here, we investigated potential mechanisms that produce a 5-phase, and possibly even a 6-phase life cycle pattern in a common Caribbean coral reef fish species Haemulon flavolineatum (French grunt) across multiple coastal habitats. At each discrete life stage, individuals were faced with important and stage-specific ecological trade-offs that could significantly augment fitness. Pelagic larvae settled on rubble habitats near bay entrances where they reached an optimum between predation risk (survival) and food abundance (growth). Individuals subsequently shifted to seagrass beds, likely as a result of increased food resources, followed by a shift to mangroves as predation refugia. Before the unidirectional movement between bays and coral reefs, some fishes shifted from mangroves to boulder/notch habitats. Likely, this habitat serves as an intermediate stop before their final shift to the coral reef, where they reach maturity and reproduce. This study reveals ecological linkages and flows among habitat types that are of direct conservation importance to these ecosystems. Furthermore, the identification of mechanisms that give rise to cross-habitat distribution patterns of marine fishes in general might lead to enhanced conservation management solutions to declines in fisheries at larger scales.
\end{abstract}

KEY WORDS: Ontogenetic habitat shifts $\cdot$ Life cycle $\cdot$ Nursery $\cdot$ Food abundance $\cdot$ Condition $\cdot$ Maturation · Trade-offs

Resale or republication not permitted without written consent of the publisher

\section{INTRODUCTION}

Life cycles spanning multiple life stages and habitats are taxonomically and ecologically widespread. For example, amphibians (Werner 1986), insects (Schäfer et al. 2006), and crustaceans (Haywood \& Kenyon 2009) all show dramatic ontogenetic habitat shifts between neighboring aquatic and terrestrial en- vironments. The strategy of utilizing different habitats through ontogeny is assumed to confer distinct advantages for individuals at each life stage, thereby maximizing cumulative fitness (Stephens \& Krebs 1986, Sutherland 1996). Body size variations are strongly linked to shifts in habitat use and could arise from changing resource needs (Werner \& Gilliam 1984, Cocheret de la Morinière et al. 2003), predation 
risk (Shulman 1985, Laegdsgaard \& Johnson 2001), or reproduction in optimal habitat for larval survival and dispersal (reviews by Johannes 1978, Nemeth 2009). Yet, transitions between habitats are energetically costly and dangerous, indicating that spatial tradeoffs exist between energy and predation risk for many animals (Kaufman et al. 1992, Zollner \& Lima 2005).

In marine environments, one of the more common life cycles is 2-phased and involves a dispersive larval phase and a demersal juvenile and adult phase (Leis 1991, Mora \& Sale 2002). However, some species frequently undergo several distinct life stages in which demersal juveniles and adults are also spatially segregated (Parrish 1989, Verweij et al. 2008, Jones et al. 2010). Differential utilization of juvenile habitats based on habitat specific exploitation of the cost-to-benefit ratio could aid in maximizing net fitness benefits for individuals. However, the avoidance of predation (minimizing mortality risk), and increased acquisition of resources (maximizing growth rate), or reduction of the ratio of mortality to growth are all variable in both space and time (Lima \& Dill 1990, Dahlgren \& Eggleston 2000, Haywood \& Kenyon 2009).

Tropical coastlines contain ubiquitous examples of complex seascapes. In shallow, clear water they often harbor mangrove, seagrass, macroalgal, and reef habitats located in wave-protected embayments, lagoons or estuaries. Such habitats have long been presumed to function as important nurseries for numerous offshore fish species (Parrish 1989, Heck et al. 2003, Nagelkerken 2009). Their high structural complexity provides advantages in terms of higher food abundances and increased survival from predation (Laegdsgaard \& Johnson 2001). However, recent studies have suggested that food is not necessarily higher in nurseries than in adult habitats, and fish may trade-off growth for increased survival in nursery habitats (Grol et al. 2008, 2011, Kimirei et al. 2013).

While it is clear that certain habitats provide benefits during key life stages (Dahlgren \& Eggleston 2000), the relative (dis)advantages of many habitats remain unknown. For example, if different nursery habitats provided equivalent benefits (e.g. higher survival and higher food abundances) then animals would be expected to be randomly distributed amongst these habitats. However, there is ample evidence for a multitude of crustacean and fish species demonstrating clear size-based habitat shifts, and thus also varying advantages and disadvantages among nursery habitat types (Rooker \& Dennis 1991, Nagelkerken et al. 2000c, Burke et al. 2009). Previous studies have essentially failed to address the mecha- nisms underlying ontogenetic movements among ostensibly profitable nursery habitats that produce these distributional patterns. Furthermore, addressing this topic is logistically difficult due to population and hydrologic connectivity (e.g. through short-term tidal and diel migrations).

In the present study, we tackle the question of why marine animals shift between multiple nursery habitats through ontogeny if indeed nurseries provide a similar suite of benefits as is generally assumed. Our model fish species is the French grunt Haemulon flavolineatum, as it occupies multiple habitats throughout its life cycle (Nagelkerken et al. 2000c, AguilarPerera \& Appeldoorn 2008). This species is widely distributed in the western Atlantic Ocean and adults are frequently encountered on coral reefs (Nagelkerken et al. 2000b, Mateo et al. 2010) where they spawn throughout the year (McFarland et al. 1985). Larvae settle in bay environments such as mangroves and seagrass beds (Pollux et al. 2007, Grol et al. 2011), where they feed diurnally upon zooplankton. As they grow larger, they shift to zoobenthivory and migrate among nearby habitats to feed nocturnally (Verweij \& Nagelkerken 2007, Appeldoorn et al. 2009). Other habitat shifts are driven by changes in predation risk or by the readiness to reproduce (Grol et al. 2011). However, knowledge on the latter has been highly limited. In this study, we test the hypothesis that pervasive shifts among nursery habitats are driven by factors such as resource acquisition - which is integrated and expressed through habitat-based differences in growth rate, maturation rate, and condition. We further hypothesize that due to a lower predation risk in nurseries than adult habitats (Dorenbosch et al. 2009, Grol et al. 2011), factors other than predation risk (e.g. food availability) play a larger role in explaining ontogenetic shifts between nursery habitats. The results of this study provide an itemized description of life history traits that act as the underlying mechanisms leading to differential distributions of marine organisms across tropical coastal habitats at various life cycle stages. Understanding these mechanisms is an important step towards improved reef fisheries conservation management.

\section{MATERIALS AND METHODS}

\section{Model species}

Our model fish species is the French grunt Haemulon flavolineatum. This species is commercially important, and occupies several different habitats as 
juveniles (e.g. mangrove, seagrass, rubble) where they form large schools, but is largely restricted to coral reefs as adults where they occur in smaller groups or as solitary individuals (Nagelkerken 2007). Larvae have a dispersive oceanic life stage and typically settle within $15 \mathrm{~d}$ following fertilization (McFarland et al. 1985) at a size of 8 to $12 \mathrm{~mm}$ fork length (FL). At the onset of maturity ( 14 to $18 \mathrm{~cm} \mathrm{FL),} \mathrm{fish}$ migrate to coral reefs to join the spawning adult population (Grol et al. 2011). From settlement ( $1 \mathrm{~cm}$ FL) up to $\sim 5 \mathrm{~cm} \mathrm{FL}$, French grunts in our study area are diurnal planktivores feeding mainly on Copepoda; however, at larger sizes they switch to nocturnal predation on zoobenthos (Verweij et al. 2006b). Natural predators of $H$. flavolineatum can be diverse, but typically include large juvenile and adult predator fish species. At Curaçao, these include Ocyurus chrysurus and Lutjanus apodus in bay environments, while Aulostomus maculates is a common predator on the reef (Dorenbosch et al. 2009). The risk of predation is highest during the nocturnal and dusk periods compared to diurnal periods (Danilowicz \& Sale 1999).

Haemulon flavolineatum of different sizes were caught using hand lines and fish traps. The traps were baited with squid, and thus any squid flesh found in the gut content was excluded from the diet analyses. After fish were caught, they were put on ice and transported to the laboratory where they were frozen until further analysis (i.e. dietary, condition, growth and maturation). We used Lindeman \& Richards (2005) as an identification guide to positively identify individuals of the early life stage (ca. $<1.5$ total length, TL).

\section{Study area}

This study was conducted at the southern Caribbean islands of Curaçao and Aruba (Fig. 1). At Curaçao, 2 wave-protected embayments were selected: Spanish Water Bay $\left(12^{\circ} 04^{\prime} \mathrm{N}\right.$, $\left.68^{\circ} 51^{\prime} \mathrm{W}\right)$ and Fuik Bay $\left(12^{\circ} 02^{\prime} \mathrm{N}\right.$, $\left.68^{\circ} 49^{\prime} \mathrm{W}\right)$. At Aruba, a large lagoon protected from the ocean by small coral cays was selected $\left(12^{\circ} 28^{\prime} \mathrm{N}, 69^{\circ} 59^{\prime} \mathrm{W}\right)$. All 3 embayments/lagoon (further referred to as 'bays') were connected to an adjacent fringing coral reef through single (Curaçao) or multiple (Aruba) narrow entrances. The bays were predominantly shallow ( $<5 \mathrm{~m}$ depth) and their shorelines were fringed with mangroves Rhizophora mangle and seagrass Thalassia testudinum beds. Parts of their shorelines consisted of a fossilized limestone plateau containing numerous undercut crevices. Rocks and boulders are often present directly in front of crevices, and this entire hard bottom
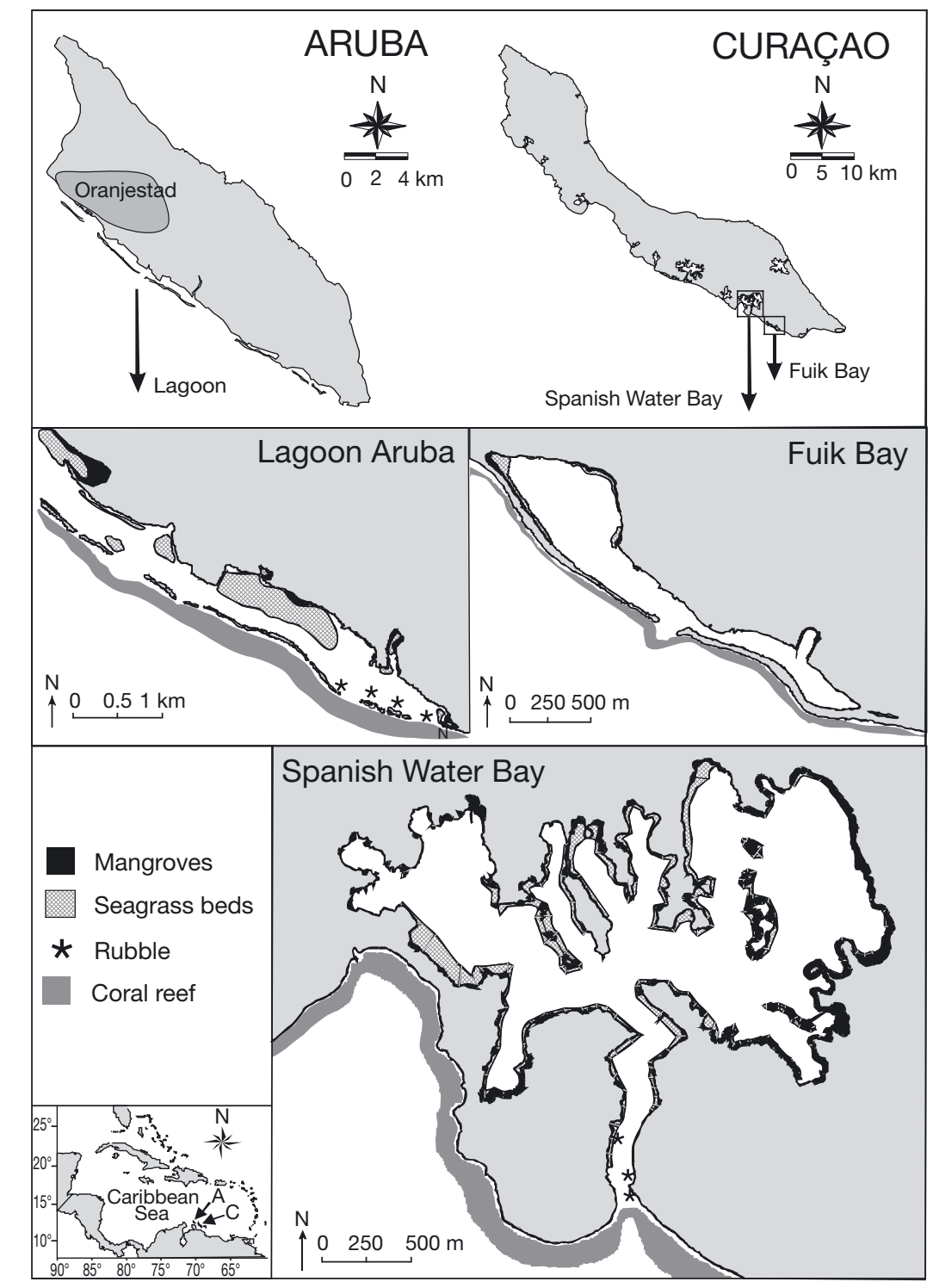

Fig. 1. The 3 study locations: the lagoon at Aruba (A), and Fuik Bay and Spanish Water Bay at Curaçao (C). The locations of mangroves, seagrass beds and coral reefs are indicated for each study location. Rubble habitats are only present in the connections between the bays and the adjacent coral reefs at Spanish Water Bay at Curaçao and the lagoon at Aruba 
environment is hereafter referred to as the 'boulder/ notch' habitat ( 1.5 m deep). Connections between bay areas and reefs consisted of sandy substratum harboring scattered pieces of dead branching corals such as Acropora cervicornis and Madracis mirabilis (hereafter referred to as 'rubble' habitat). Southwestern coastlines at both islands consisted of a continuous fringing coral reef.

\section{Ontogenetic habitat use}

Abundance and TL of Haemulon flavolineatum were visually estimated by divers using SCUBA or snorkeling gear (see Nagelkerken et al. 2000b) along permanent belt transects established in 5 coastal habitats (i.e. mangrove, seagrass, rubble, boulder/ notch habitat, coral reef) at Aruba (July to December 2007) and Curaçao (Spanish Water Bay: July to November 2005) but not at Fuik Bay. At each island, 2 to 5 sites were selected per habitat type and 2 to 9 permanent transects established at each site, depending on the total surface area of the habitat patches and the water clarity (for visual surveys) at each site. Although the number of sites and number of transects per site varied, the total number of transects surveyed per habitat type was similar between islands, with the exception of the fringing reef on Curaçao. Here, only the reef in front of the mouth of the bay was surveyed as there was only a single channel connecting the bay to the reef; at Aruba the lagoon was connected to the reef through multiple channels and therefore a larger number of reef sites were surveyed there. In total, the number of permanent transects surveyed at Aruba was as follows: mangroves 18, seagrass 22, rubble 22, and reef 22 transects; on Curaçao: mangroves 15, seagrass 24, rubble 17, and reef 10 transects. At each site, the location of the first transect was randomly selected, and subsequent transects were separated by at least $25 \mathrm{~m}$. Transects were $25 \mathrm{~m}$ long and $4 \mathrm{~m}$ wide $\left(100 \mathrm{~m}^{2}\right)$, except for mangrove transects which were shorter because of the relatively small sizes of the mangrove stands. Surveys were repeated at least once every $10 \mathrm{~d}$ at each site, and each transect was censused a minimum of 6 times in total during the entire study period at Curaçao and 3 to 4 times at Aruba, respectively. Total fish length was estimated in size increments of $2 \mathrm{~cm}$ by experienced observers. Observers had practiced size estimations on nonmoving objects underwater before starting the visual surveys, and continued practicing throughout the study period. To calculate total population sizes in the different bay habitats (Fig. 2c,d), fish densities were multiplied by the respective total habitat surface area for each size class of fish.

\section{Diet and food abundance}

Gut contents of a total of 478 fish were analyzed in the 5 habitats at the 3 bay locations (see Table S1 in the Supplement at www.int-res.com/articles/suppl/ m502p229_supp.pdf). The gut contents of each fish were identified and quantified to taxon level using a stereomicroscope (see Cocheret de la Morinière et al. 2003). Plant material and sand were not taken into account, while empty guts and guts in which the contents were $100 \%$ unidentifiable were excluded from the analyses. Relative volumetric abundance of food items was estimated by eye, where the total volume of contents of the digestive tract was set at $100 \%$.

Abundances of potential prey items were quantified from the top layer of the substratum (upper $4 \mathrm{~cm}$ ) and from the water column just above the substratum in all habitats (except the boulder/notch habitat) at Spanish Water Bay and at Aruba. Plankton samples were collected by randomly hauling a plankton net (6 times in total) along a $1 \mathrm{~m}$ long transect, whereas benthic samples were randomly collected using a core to collect the upper $4 \mathrm{~cm}$ of the substratum. Samples were taken during the day and preserved in $70 \%$ ethanol. Before analysis in the laboratory, samples were stained with Bengal Rose for improved contrast during the sorting process. All zooplankton and benthic invertebrates were categorized to taxon level using a stereomicroscope (see Grol et al. 2008 for further details). In total, 111 sediment samples and 60 plankton samples were collected at Spanish Water Bay, and 108 sediment and 53 plankton samples at Aruba, respectively. Identification and quantification of planktonic and benthic invertebrates in each sample were estimated using the same method as above for gut contents of fish.

\section{Condition}

Body condition was evaluated for fish caught in the 5 habitats at the 3 bay locations on the basis of 2 metrics (see Table S1 in the Supplement): (1) body weight to length ratio ('WL ratio', based on eviscerated wet weight and FL) (1861 fish), and (2) liver-lipid content (914 fish). To estimate the total lipid content, the wet weight of livers was determined to an accuracy of $0.00001 \mathrm{~g}$, and total lipids extracted from each liver 
by homogenizing tissue with a chloroform:methanol: water solvent $(1: 1: 1)$ according to Bathgate et al. (2006). Extracted lipids were dried and weighed to an accuracy of $0.00001 \mathrm{~g}$, and expressed as a percentage of wet liver weight.

\section{Growth}

For fish caught in each habitat (except boulder/ notch habitat) at Spanish Water Bay and at Aruba (693 in total, Table S1 in the Supplement), sagittal otoliths were removed from each fish and the left otolith used for age determination under a dissecting microscope utilizing reflected light (see DeVries \& Frie 1996). Ages were determined blindly (e.g. with no knowledge of the sample number or fish size) twice by an experienced reader, and disagreements between reads 1 and 2 (4\% of all samples) were settled using another experienced reader.

\section{Maturation}

Reproductive status of each fish caught in the 5 habitats at the 3 bay locations (1775 in total; Table S1 in the Supplement) was assessed based on external macroscopic sexual characteristics of the gonads (e.g. size, color, shape and texture). Male gonads are more whitish/yellowish, while female gonads are more reddish/brownish. The size, roundness and thickness of the gonads, the structure on the outside, and presence of veins or visual presence of oocytes are examples of identification features we used. Each individual was classified into immature (Stage 1 and 2) and mature (Stage 3 to 6) based on 6 different maturation stages using a modified protocol of Ntiba \& Jaccarini (1990) and Kulmiye et al. (2002), in which Stages $2 \mathrm{a}$ and $2 \mathrm{~b}$ were combined.

Wet weight of both gonads of each fish (1753 fish in total; Table S1 in the Supplement) was determined to an accuracy of $0.001 \mathrm{~g}$ and was used to calculate the gonadosomatic index (GSI): GSI $=[G W /(W-G W)] \times$ 100 , where $G W$ is the wet weight of both gonads and $W$ the eviscerated wet body weight (Ntiba \& Jaccarini 1990, Kulmiye et al. 2002).

\section{Survival from predation}

Relative predation risk for tethered Haemulon flavolineatum was estimated for all habitats (except boulder/notch habitat) at Spanish Water Bay and at
Aruba (480 in total; Table S1 in the Supplement) during the day at the same locations where visual surveys were conducted. Tethering trials were conducted for 3 life stages: early juveniles (3 to $4 \mathrm{~cm} \mathrm{FL),}$ approximate size at which fish start migrating to reefs (8 to $12 \mathrm{~cm} \mathrm{FL),} \mathrm{and} \mathrm{adult} \mathrm{fish} \mathrm{commonly} \mathrm{found}$ on reefs (14 to $17 \mathrm{~cm}$ FL). This selection was based on the most commonly found size classes; due to time and logistic limitations we were not able to include all possible size classes. On average, 24 fish were tested per life stage per habitat per bay. In each habitat, 2 or 3 replicate trials were conducted, each including an average of 10 concurrently tethered fish (see Grol et al. 2011).

Individual fish were secured to a thin monofilament tether line using a small barbed hook on one end of the line which was threaded through the lower jaw, while the other end was attached to an iron $\operatorname{rod}(\sim 40 \mathrm{~cm})$ pressed into the substratum. The monofilament was rated at $\sim 5 \mathrm{~kg}$ breaking force so it was not possible for larger fish to break the line. Tether lines were $50 \mathrm{~cm}$ long for early juveniles (since they were not very active), while the more active fish $(\geq 8.0 \mathrm{~cm}$ ) were tethered to a line of $80 \mathrm{~cm}$ length. Each fish was able to hide within surrounding vegetation (when present), between corals on the reef, or between pieces of broken coral in the rubble habitat. Only fish that survived and were alive, or that had clearly been attacked or eaten (i.e. hook and/or part of the line missing) at the end of the 90 min trial were considered successful and included in the analyses; dead and possibly detached fish (i.e. line and hook undamaged) were excluded.

Tethering was used to measure relative predation risk, i.e. to assess the effect of habitat and fish size on predation risk, not to measure absolute rates of predation. Although tethering experiments can produce biases that can confound results (Peterson \& Black 1994), it is a widely used method to measure relative predation risk on a diverse suite of fish and invertebrate prey species (Shulman 1985, Acosta \& Butler 1999, Dahlgren \& Eggleston 2000, Baker \& Sheaves 2007, Dorenbosch et al. 2009). As the same tethering method was used across all habitats for the different fish size classes, possible tethering artifacts among treatments were expected to be relatively consistent (e.g. Aronson \& Heck 1995).

\section{Statistical analyses}

Differences among habitats with respect to diet composition were tested using a chi-squared $\left(\chi^{2}\right)$ test 
for each size class per bay separately. To explore statistical differences among habitats for the abundance of food, mean WL ratio, liver-lipid content, maturation stage and GSI, 1-way ANOVAs followed by a Hochberg's GT2 (when sample sizes varied greatly) or a Tukey's HSD (when sample sizes were similar) posthoc comparison were performed for data which had homogeneous variances (tested with a Levene's test). If the latter was not the case, non-parametric KruskalWallis tests followed by a Games Howell post-hoc comparison were used. The Games Howell post-hoc test is also accurate when sample sizes are unequal (Field 2006). Data were transformed using a $\log (x+1)$ or square root $(x+0.5)$ transformation if needed. When only 2 habitat types were compared, a $t$-test for independent samples was used. All analyses were done separately for the 3 bays, and for fish belonging to $4 \mathrm{~cm}$ incremental length classes, as these represented independent life stages with different ecological traits occupying different habitats. Statistical analyses were conducted with SPSS version 15.0, and p-values $\leq 0.05$ were considered statistically significant.

Whereas growth could potentially be completed over a variety of habitat types and was generally non-asymptotic-often approaching linearity in form-differences in growth between habitats on each island were evaluated using analyses of covariance (ANCOVAs). Two ANCOVA models were conducted (one for each island) and in these models, FL was the dependent variable, $\log _{10}$ (age) was a covariate, and habitat type was a categorical variable (Rypel 2011). Among habitat, differences at each island in mean length-at-age (i.e. regression elevation) and growth rates (i.e. regression slopes, quantified as the site $\times \log _{10}(\mathrm{age})$ interaction) were evaluated using Bonferroni post-hoc tests.

At each island, differences in survival rates among habitats for each size class were compared using logistic regressions and post-hoc $\chi^{2}$ tests with survival of individual fish (0 or 1 ) as a dependent variable, and habitat as an independent class variable.

\section{RESULTS}

\section{Ontogenetic habitat use}

Haemulon flavolineatum $<4 \mathrm{~cm}$ TL were restricted to bay environments, whereas the largest individuals caught were restricted to reefs (Fig. 2a,b). During
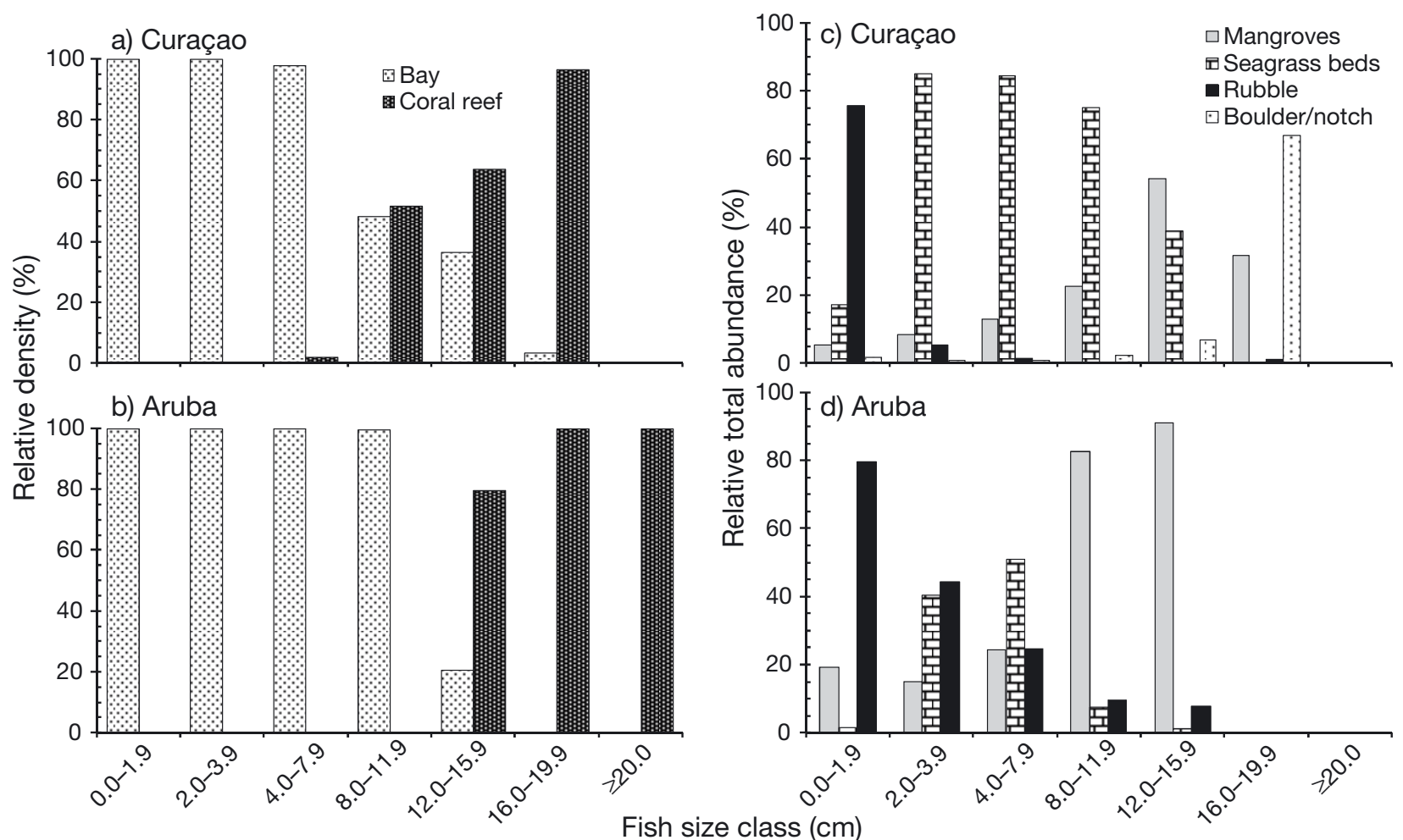

Fig. 2. Haemulon flavolineatum. Relative density of French grunts in bays (all habitats pooled) and on coral reefs for (a) Curaçao (Spanish Water Bay) and (b) Aruba, and relative total abundance (i.e. fish density $\times$ habitat surface area) for individual bay habitats for (c) Curaçao and (d) Aruba, per $4 \mathrm{~cm}$ size classes. Note that the size class 0.0 to $3.9 \mathrm{~cm}$ TL is separated into 0.0 to $1.9 \mathrm{~cm}$ and 2.0 to $3.9 \mathrm{~cm} \mathrm{TL}$, and that at Aruba the boulder/notch habitat was not included in the study 
Table 1. Haemulon flavolineatum. Relative volume $( \pm \mathrm{SD})$ of Copepoda, Tanaidacea, benthic worms and Decapoda found in the digestive tracts of French grunts collected in mangroves (MG), seagrass beds (SG), rubble habitats (RB), boulder/notch habitats (BN) and on coral reefs (RF) per $4 \mathrm{~cm}$ size class per location per island. $\mathrm{n}=$ number of analyzed digestive tracts per habitat per size class per location per island. Positive associations between diet components and habitat for $H$. flavolineatum are highlighted in grey, and were tested separately for each size class in each bay (separate tests for size classes for Spanish Water Bay: range $\chi^{2}{ }_{3-12}=60$ to 283 , all $p<0.001$; separate tests for size classes for Fuik Bay: range $\chi^{2}{ }_{3-9}=24$ to 165 , all $p<0.001$; separate tests for size classes for Lagoon: range $\chi_{3-9}^{2}=39$ to 226 , all $p<0.001$ )

\begin{tabular}{|c|c|c|c|c|c|c|c|c|}
\hline Island & Location & Size $(\mathrm{cm})$ & Habitat & $\mathrm{n}$ & Copepoda & Tanaidacea & Worms & Decapoda \\
\hline \multirow[t]{12}{*}{ CURAÇAO } & Spanish & \multirow[t]{4}{*}{$4.0-7.9$} & MG & 15 & $53 \pm 26$ & $27 \pm 24$ & $0 \pm 1$ & $1 \pm 1$ \\
\hline & \multirow[t]{11}{*}{ Water Bay } & & $\mathrm{SG}$ & 15 & $52 \pm 21$ & $23 \pm 26$ & $0 \pm 0$ & $1 \pm 1$ \\
\hline & & & $\mathrm{BN}$ & 2 & $13 \pm 18$ & $38 \pm 53$ & $0 \pm 0$ & $0 \pm 0$ \\
\hline & & & $\mathrm{RF}$ & 27 & $68 \pm 27$ & $2 \pm 7$ & $1 \pm 3$ & $4 \pm 13$ \\
\hline & & \multirow[t]{5}{*}{$8.0-11.9$} & MG & 17 & $8 \pm 9$ & $49 \pm 42$ & $4 \pm 9$ & $25 \pm 35$ \\
\hline & & & $\mathrm{SG}$ & 17 & $13 \pm 24$ & $46 \pm 42$ & $6 \pm 24$ & $1 \pm 4$ \\
\hline & & & $\mathrm{RB}$ & 14 & $39 \pm 49$ & $0 \pm 0$ & $8 \pm 20$ & $17 \pm 31$ \\
\hline & & & $\mathrm{BN}$ & 24 & $15 \pm 26$ & $22 \pm 32$ & $7 \pm 14$ & $14 \pm 31$ \\
\hline & & & $\mathrm{RF}$ & 4 & $7 \pm 14$ & $9 \pm 18$ & $45 \pm 35$ & $27 \pm 38$ \\
\hline & & \multirow[t]{2}{*}{$12.0-15.9$} & $\mathrm{BN}$ & 5 & $26 \pm 42$ & $0 \pm 0$ & $10 \pm 15$ & $16 \pm 26$ \\
\hline & & & $\mathrm{RF}$ & 30 & $10 \pm 18$ & $0 \pm 2$ & $13 \pm 16$ & $24 \pm 30$ \\
\hline & & $16.0-19.9$ & $\mathrm{RF}$ & 2 & $0 \pm 0$ & $0 \pm 0$ & $10 \pm 14$ & $49 \pm 16$ \\
\hline \multirow[t]{9}{*}{ CURAÇAO } & \multirow[t]{9}{*}{ Fuik Bay } & \multirow[t]{2}{*}{$4.0-7.9$} & MG & 3 & $67 \pm 58$ & $0 \pm 0$ & $0 \pm 0$ & $0 \pm 0$ \\
\hline & & & $\mathrm{SG}$ & 6 & $53 \pm 43$ & $18 \pm 40$ & $12 \pm 19$ & $11 \pm 20$ \\
\hline & & \multirow[t]{4}{*}{$8.0-11.9$} & MG & 20 & $36 \pm 36$ & $8 \pm 21$ & $5 \pm 15$ & $3 \pm 11$ \\
\hline & & & SG & 6 & $31 \pm 43$ & $17 \pm 41$ & $0 \pm 0$ & $0 \pm 0$ \\
\hline & & & BN & 16 & $9 \pm 26$ & $0 \pm 1$ & $24 \pm 41$ & $13 \pm 32$ \\
\hline & & & $\mathrm{RF}$ & 8 & $36 \pm 29$ & $0 \pm 0$ & $22 \pm 34$ & $4 \pm 13$ \\
\hline & & \multirow[t]{2}{*}{$12.0-15.9$} & $\mathrm{BN}$ & 13 & $6 \pm 12$ & $0 \pm 0$ & $4 \pm 14$ & $8 \pm 28$ \\
\hline & & & $\mathrm{RF}$ & 21 & $15 \pm 26$ & $6 \pm 22$ & $18 \pm 26$ & $27 \pm 33$ \\
\hline & & $16.0-19.9$ & $\mathrm{RF}$ & 5 & $1 \pm 3$ & $0 \pm 1$ & $6 \pm 9$ & $66 \pm 23$ \\
\hline \multirow[t]{13}{*}{ ARUBA } & \multirow[t]{13}{*}{ Lagoon } & \multirow[t]{4}{*}{$4.0-7.9$} & MG & 18 & $40 \pm 21$ & $18 \pm 17$ & $4 \pm 12$ & $5 \pm 14$ \\
\hline & & & SG & 46 & $23 \pm 28$ & $52 \pm 32$ & $1 \pm 3$ & $7 \pm 14$ \\
\hline & & & $\mathrm{RB}$ & 14 & $44 \pm 32$ & $21 \pm 29$ & $5 \pm 11$ & $8 \pm 18$ \\
\hline & & & $\mathrm{RF}$ & 14 & $79 \pm 12$ & $7 \pm 10$ & $0 \pm 1$ & $2 \pm 3$ \\
\hline & & \multirow{4}{*}{$8.0-11.9$} & MG & 21 & $18 \pm 26$ & $29 \pm 34$ & $3 \pm 6$ & $14 \pm 28$ \\
\hline & & & $\mathrm{SG}$ & 15 & $19 \pm 38$ & $0 \pm 0$ & $0 \pm 0$ & $0 \pm 0$ \\
\hline & & & $\mathrm{RB}$ & 27 & $19 \pm 25$ & $8 \pm 15$ & $15 \pm 31$ & $13 \pm 27$ \\
\hline & & & $\mathrm{BN}$ & 3 & $44 \pm 46$ & $7 \pm 12$ & $0 \pm 0$ & $0 \pm 0$ \\
\hline & & \multirow{3}{*}{$12.0-15.9$} & $\mathrm{RB}$ & 18 & $24 \pm 28$ & $4 \pm 9$ & $7 \pm 13$ & $20 \pm 30$ \\
\hline & & & $\mathrm{BN}$ & 8 & $19 \pm 34$ & $4 \pm 11$ & $1 \pm 3$ & $22 \pm 41$ \\
\hline & & & $\mathrm{RF}$ & 3 & $4 \pm 7$ & $7 \pm 12$ & $5 \pm 5$ & $24 \pm 7$ \\
\hline & & \multirow[t]{2}{*}{$16.0-19.9$} & $\mathrm{RB}$ & 3 & $9 \pm 15$ & $2 \pm 3$ & $8 \pm 11$ & $76 \pm 21$ \\
\hline & & & $\mathrm{RF}$ & 18 & $1 \pm 3$ & $0 \pm 0$ & $15 \pm 14$ & $51 \pm 28$ \\
\hline
\end{tabular}

bay occupancy, fishes showed a change in their relative abundance across habitats with increasing size (Fig. 2c,d). Oceanic larvae settled almost exclusively in the rubble habitat located in the mouths of the bays. Size-frequency distribution patterns for consecutive life stages suggested ontogenetic habitat shifts from rubble to seagrass (starting at $\sim 2 \mathrm{~cm} \mathrm{TL}$ ), from seagrass to mangrove (at $\sim 8$ to $12 \mathrm{~cm} \mathrm{TL}$ ), and from bay habitats to coral reefs (at $\sim 8$ to $16 \mathrm{~cm} \mathrm{TL}$ ). For the few large fishes that remained at Spanish Water Bay, a possible habitat shift was present from mangrove to boulder/notch habitat (at $\sim 16$ to $20 \mathrm{~cm}$ TL; Fig. 2c). Fishes $\geq 20 \mathrm{~cm}$ TL were absent from the bay and only found on the reef.

\section{Diet and food abundance}

Gut content analyses showed that diet of Haemulon flavolineatum was size- rather than habitatdependent (Table 1). Up to $\sim 12.0 \mathrm{~cm}$ FL fish consumed primarily Copepoda (up to $79 \%$ of the total stomach content on average) and Tanaidacea (up to $52 \%$ ). With increasing fish size, a switch in diet was noticeable towards larger-sized decapod crustaceans (up to $76 \%$ ) and benthic worms (up to $18 \%$ ).

The 2 preferred food items (i.e. copepods and tanaids) of juvenile Haemulon flavolineatum $(<12.0 \mathrm{~cm}$ FL) generally occurred at higher densities in seagrass beds than in other bay habitats (Fig. 3, Table S2 in 

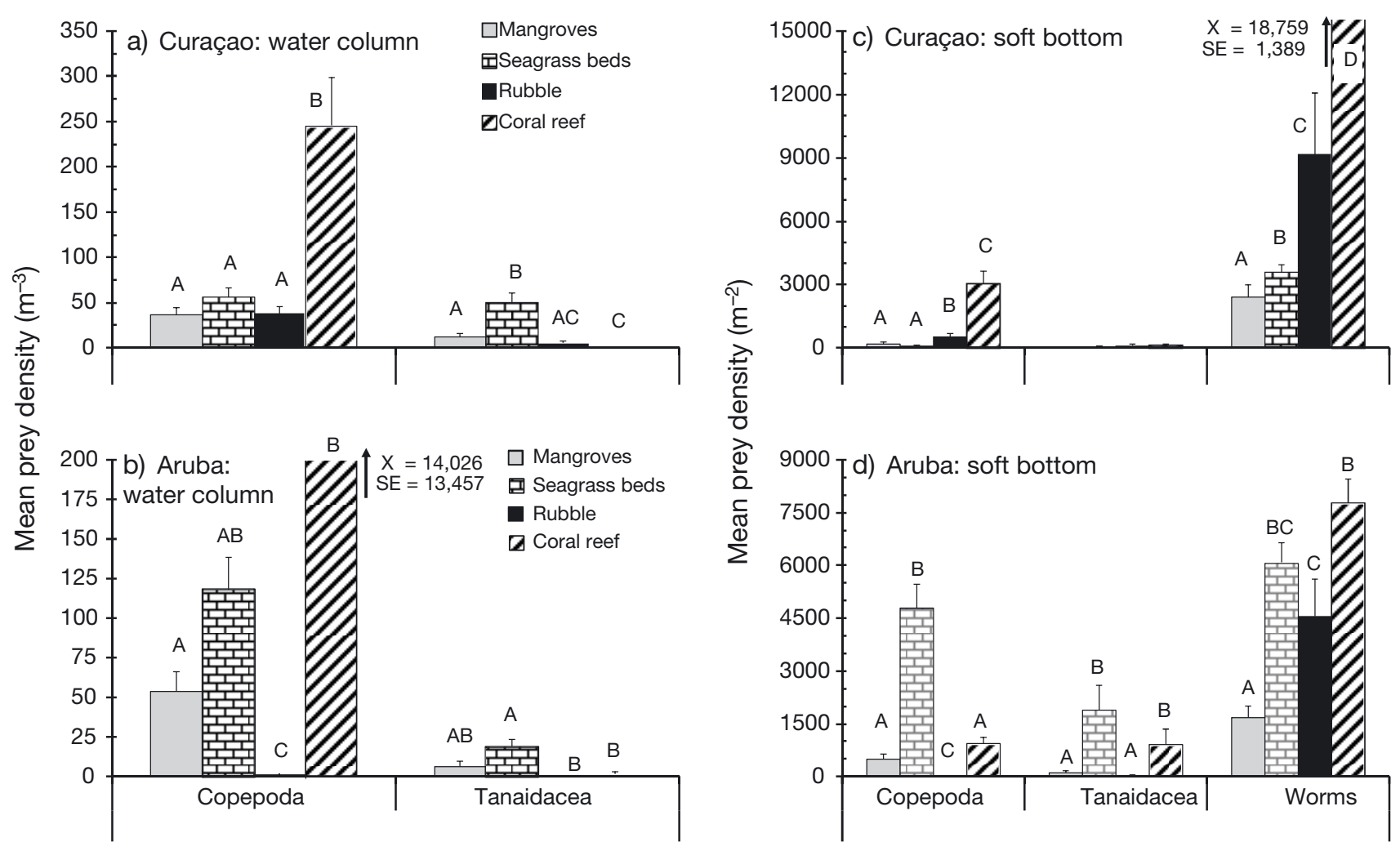

Fig. 3. Haemulon flavolineatum. Mean (+SE) densities of preferred prey items (Copepoda, Tanaidacea, benthic worms) in $(a, b)$ the water column and $(c, d)$ in the soft bottom of individual habitats at $(a, c)$ Curaçao (Spanish Water Bay) and (b,d) Aruba. Different letters represent significant differences among habitat types (see details in Table S2 in the Supplement at www.intres.com/articles/suppl/m502p229_supp.pdf), per food item per bay per island (Tukey's HSD and Games Howell post-hoc comparisons, $\mathrm{p} \leq 0.05$ )

the Supplement). At Aruba, copepod and tanaid densities in the water column as well as in the soft bottom were significantly higher in the second life-stage habitat (seagrass) than in the settlement habitat (rubble). At Curaçao, this pattern was less clear, with only tanaid densities in the water column being significantly higher in seagrass than rubble habitat. In the third life-stage mangrove habitat, copepod and tanaid densities were either equal or significantly lower than in the second-stage seagrass habitat. Overall, densities of planktonic copepods and benthic worms (preferred by larger fish) were highest on the adult reef habitat and lowest in the bay habitats.

\section{Condition}

The higher food abundances in the seagrass beds were not reflected in the WL ratios of fish (Fig. $4 a-C$ ). For some size classes of fish, WL ratio was in fact significantly lower in seagrass than in other bay habitats (Table S3 in the Supplement). Liver-lipid content showed some significant differences among bay habitats (Fig. 4d-f, Table S3), but did not follow a straightforward pattern. For large fish $(\geq 12 \mathrm{~cm}$ FL), liver-lipid content was significantly lower in reef fish than in bay fish, whereas the WL ratio was higher on the reef.

\section{Growth}

Two significant ANCOVA models were developed for examining growth variations of Haemulon flavolineatum across habitats for both Curaçao and Aruba (Table S4 in the Supplement). Mean length-at-age was significantly higher on the coral reef than for any of the other bay habitats at Curaçao and Aruba (Fig. 5, Table S4; all Bonferroni post-hoc $\mathrm{p}<0.0001$ ). Additionally, growth rates (i.e. slopes) were significantly higher on the reef relative to all other habitats at $\mathrm{Cu}$ raçao, and for all habitats except rubble at Aruba. For bay habitats at Curaçao, mean length-at-age was significantly higher for fish from the seagrass beds than the mangroves and the rubble habitat (all Bonferroni $p<0.0001)$. Growth rates were highest on the sea- 

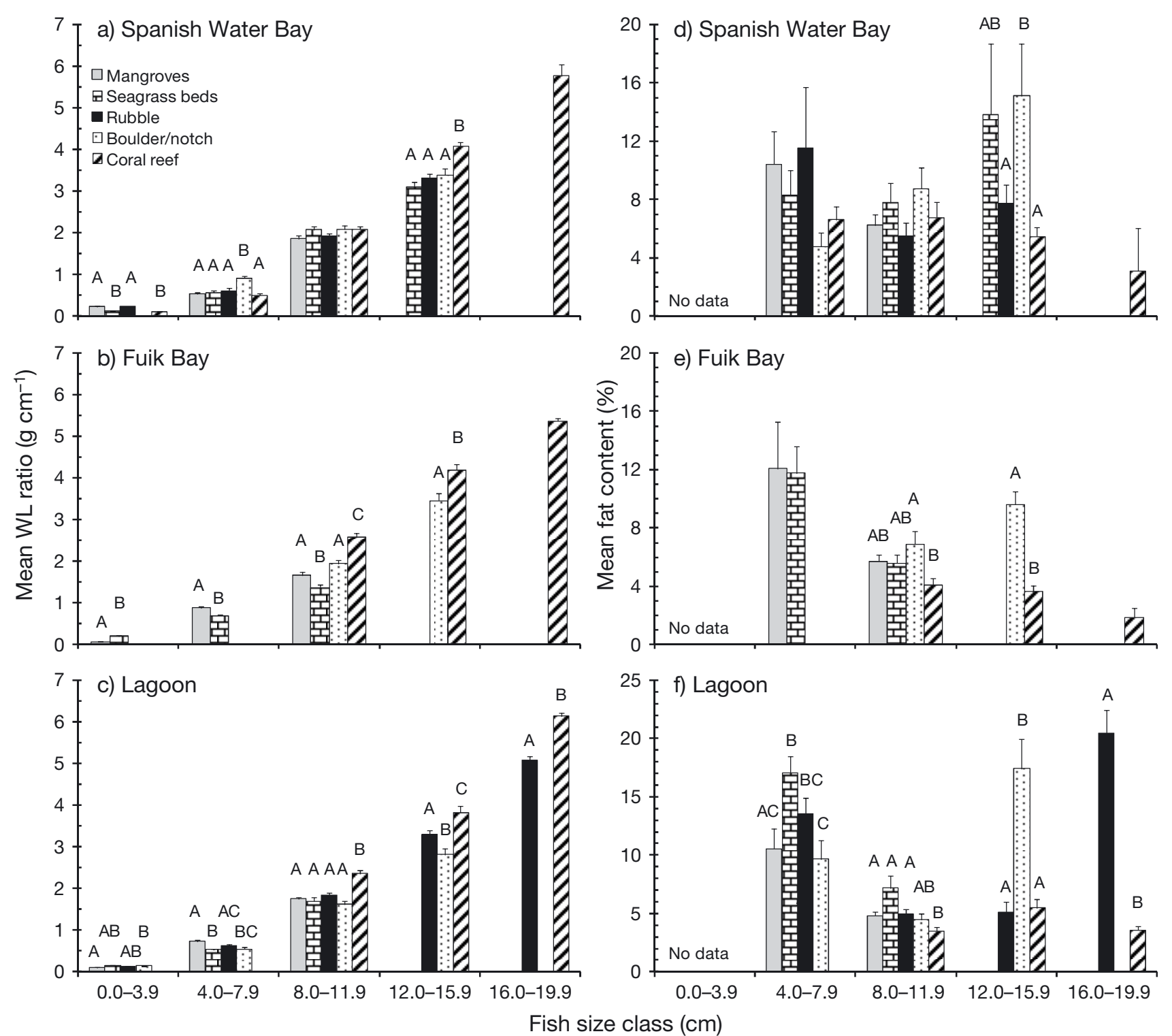

Fig. 4. Haemulon flavolineatum. Mean (+SE) weight/length ratio (WL ratio) and fat percentage of liver tissue (fat) of French grunts in individual habitats (i.e. mangroves, seagrass beds, rubble, boulder/notch and coral reef) per $4 \mathrm{~cm}$ size classes for $(\mathrm{a}, \mathrm{d})$ Spanish Water Bay and $(\mathrm{b}, \mathrm{e})$ Fuik Bay at Curaçao, and $(\mathrm{c}, \mathrm{f})$ the lagoon at Aruba. Different letters represent significant differences among habitat types (see details in Table S3 in the Supplement at www.int-res.com/articles/suppl/m502p229_ supp.pdf), per size class per bay per island (Hochberg's GT2 and Games Howell post-hoc comparisons, $\mathrm{p} \leq 0.05$ ). Note that at Aruba no significant difference in WL ratio was found for fishes of 0.0 to $3.9 \mathrm{~cm}$ fork length (FL) (Kruskal-Wallis test: $\mathrm{p}=0.181$ ), and at Fuik Bay at Curaçao no significant difference was found in fat content for fishes of 8.0 to 11.9 cm FL (Kruskal-Wallis test: $\mathrm{p}=0.193)$; however, post-hoc comparisons did show significant differences between habitats

grass beds but did not differ significantly between mangrove and rubble. At Aruba, mean length-at-age and growth rate were increased in rubble relative to seagrass habitat, and mangroves had significantly higher mean length-at-age compared to seagrass habitats. However, there was no difference in mean length-at-age for mangrove compared to rubble habitat even though rubble showed significantly faster growth rates.

\section{Gonadal development}

Gonadosomatic index showed no consistent patterns across habitats, except for higher values for large fish on coral reefs compared to the other habitats (Fig. 6). Significant differences in maturation stage were present among bay habitats, but few fish reached maturation Stage 3, indicating that they were still immature (Fig. 6, Table S3). Gonadal de- 


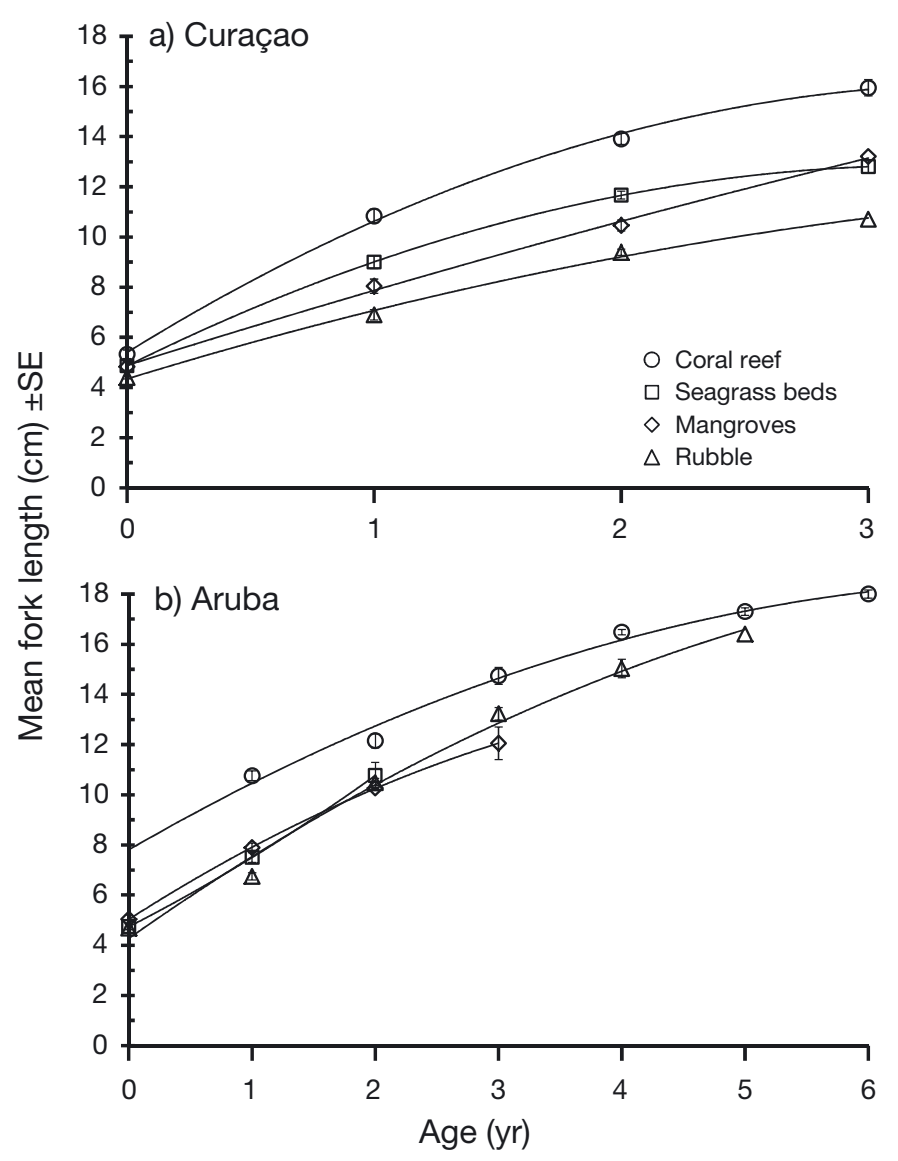

Fig. 5. Haemulon flavolineatum. Mean $( \pm \mathrm{SE})$ size-at-age for French grunts from different habitats (i.e. mangroves, seagrass beds, rubble and coral reef) at (a) Curaçao Spanish Water Bay and (b) the lagoon at Aruba. Results of statistical comparisons among habitats using ANCOVAs are presented in Table S4 in the Supplement at www.int-res.com/ articles/suppl/m502p229_supp.pdf

velopment was not consistently faster in any of the bay habitats, and full maturation (Stage 5; reflecting readiness to reproduce) was restricted to the adult reef habitat.

\section{Survival from predation}

In contrast to our expectation, rubble habitat did not show highest survival from predation compared to other bay habitats (Fig. 7, Table S5, the latter in the Supplement). During the life stage in which fish were largely restricted to the bay environment $(\leq 12.0 \mathrm{~cm}$ TL), seagrass beds at Curaçao and mangroves and seagrass beds at Aruba showed highest fish survival rates. At a size at which bay fish start moving to the reef ( $\geq 14.0 \mathrm{~cm} T L)$, there were no differences in survival rates between any of the reef or bay habitats.

\section{DISCUSSION}

The current study shows the existence of a complex, multi-stage habitat-use pattern through the ontogeny of a common coral reef fish, and provides compelling evidence for the underlying mechanisms. While many species possess a 2- or 3-phase life cycle (Roughgarden et al. 1988, Leis 1991, Haywood \& Kenyon 2009), Haemulon flavolineatum demonstrates a relatively rare and intricate 5-phase life cycle, and possibly even a 6-phase life cycle across multiple tropical shallow-water coastal habitats. After a pelagic dispersal phase (Phase 1), settlement occurs preferentially in rubble habitats (Phase 2) located near the mouth of embayments and lagoons, or water inlets between coral cays as seen at Aruba $(<2.0 \mathrm{~cm}$ TL), which is the first habitat larvae come across in our study area when entering a bay environment from the open ocean. Following settlement, small juveniles (2.0 to $7.9 \mathrm{~cm}$ TL) appear to move deeper into bays onto seagrass beds (Phase 3, which includes a pelagic feeding mode followed by a benthic feeding mode at $\sim 5 \mathrm{~cm}$ TL), especially on Curaçao. Upon growing larger (8.0 to $15.9 \mathrm{~cm}$ TL) their abundance decreased on seagrass beds, while increased in mangroves (Phase 4), especially at Aruba. Fishes $>16.0 \mathrm{~cm}$ TL residing within bays were predominantly distributed over hard substratum (i.e. boulder/ notch habitats) at Curaçao (possibly Phase 5), while at Aruba this size class was absent from all surveyed bay habitats, and boulder/notch habitats were not included in the visual surveys. Finally, fish disappeared from the bays and were only observed as adults on coral reefs (Phase 6). Our life stage distinction shows various similarities to those of grunts in the US Virgin Islands. McFarland (1980) identified 6 post-hatching stages, but with the difference that post-settlement fish of 0.4 to $2.1 \mathrm{~cm}$ SL (standard length) were associated with seagrass, sand, or Diadema urchins (as opposed to rubble in our study) and then occupied lagoon patch reefs for a size range at which our fish utilized seagrass followed by mangroves. In the next stage, fish at the Virgin Islands roamed on patch reefs followed by deeper reefs, which is similar to our fish that utilized hard bottom substrata followed by coral reefs. Likewise, Appeldoorn et al. (2009) identified 6 stages (largely overlapping with those of Shulman \& Ogden 1987) based on habitat use and behavior, and observed settlement in seagrass beds or isolated coral heads, followed by a habitat shift to lagoon patch reefs, followed by movement towards deeper reefs. In Florida, Lindeman \& Snyder (1999) identified 4 grunt life 

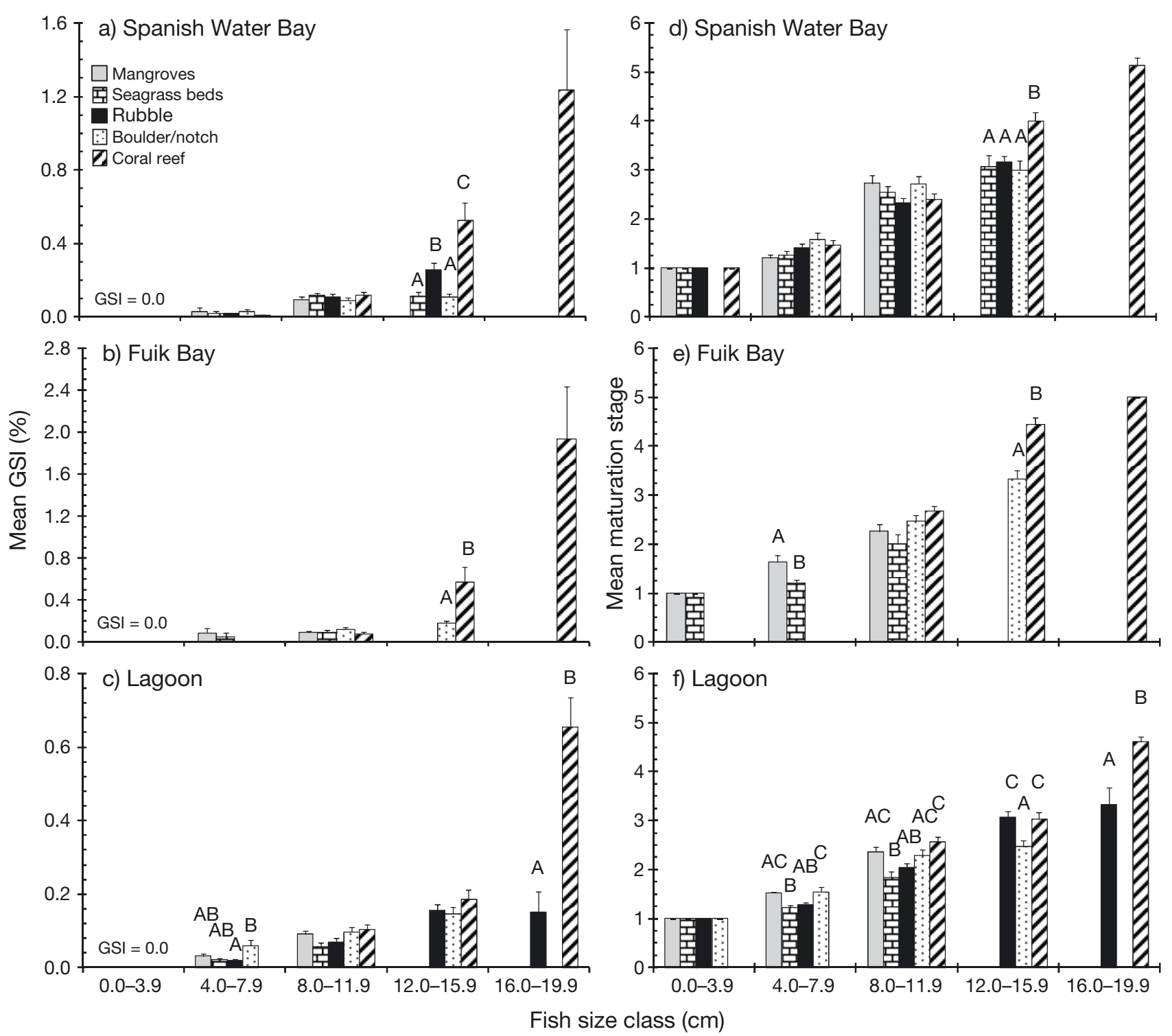

Fig. 6. Haemulon flavolineatum. Mean (+SE) gonadosomatic index (GSI) and maturation stage of French grunts in mangroves, seagrass beds, rubble, boulder/notch, and coral reef habitats averaged per $4 \mathrm{~cm}$ size classes for (a,d) Spanish Water Bay and (b,e) Fuik Bay at Curaçao, and $(\mathrm{c}, \mathrm{f})$ the lagoon at Aruba. Different letters represent significant differences among habitat types (see details in Table S3 in the Supplement at www.int-res.com/articles/suppl/m502p229_supp.pdf), per size class per bay per island (Hochberg's GT2 and Games Howell post-hoc comparisons, p $\leq 0.05$ ). Note that a significant difference among habitats was found for the mean maturation stage for fishes of 4.0 to $7.9 \mathrm{~cm}$ fork length (FL) at Spanish Water Bay (Kruskal-Wallis test: $\mathrm{p}=0.021)$; however, a post-hoc comparison did not show any significant difference between habitats

stages: $<2 \mathrm{~cm}$ (newly settled; comparable to our Stage 2 rubble fish), 2 to $5 \mathrm{~cm}$ (early juvenile; comparable to our Stage 3 seagrass fish), 5 to $15 \mathrm{~cm}$ (juvenile; comparable to our Stage 4 mangrove fish), and $>15 \mathrm{~cm}$ (adult; comparable to our Stages 5 and 6 boulder/notch and reef fish). The distinction of life phases in our study is specifically based on ontogenetic habitat use, and not on differences in coloration, morphology, pigmentation, or behavior (e.g. schooling, migration, feeding, social), which also change throughout ontogeny in this species (Helfman et al. 1982, McFarland \& Hillis 1982, Lindeman 1986). It is clear that specific habitat use of French grunts varies somewhat depending on seascape structure and availability of habitats, but all studies confirm the complex ontogenetic habitat shifts by this species. Whereas previous studies have largely been descriptive, the present study investigated the 


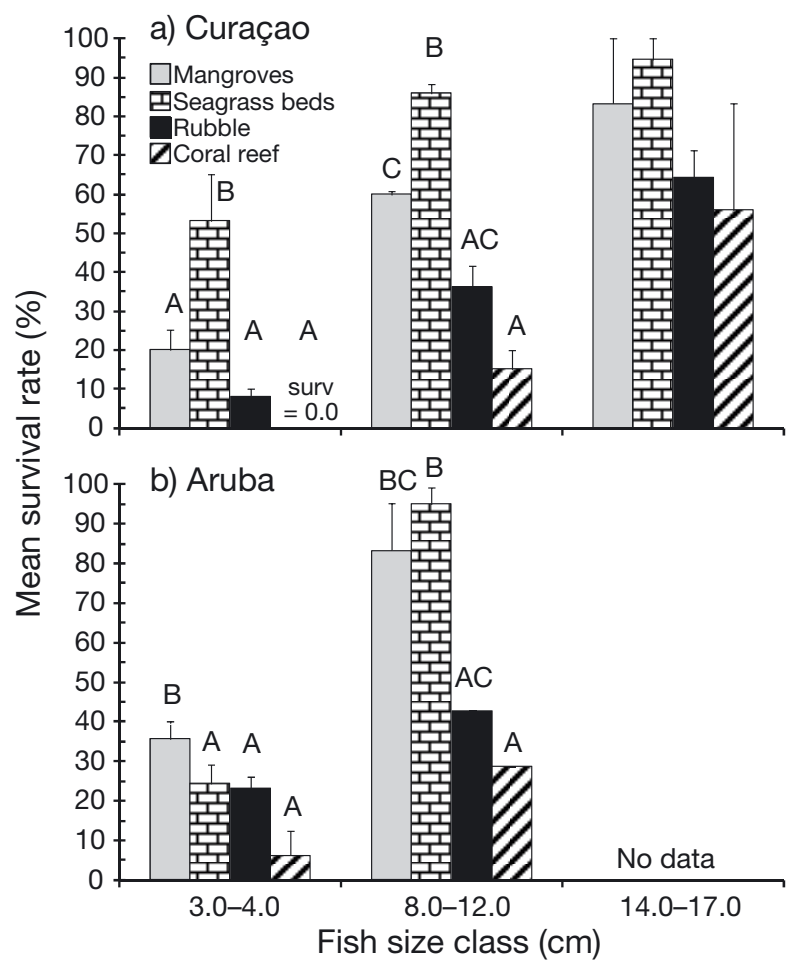

Fig. 7. Haemulon flavolineatum. Mean (+SE) survival from predation in $90 \mathrm{~min}$ for 3 different life stages of French grunts in 4 different habitats (i.e. mangroves, seagrass beds, rubble and coral reef) at (a) Spanish Water Bay at Curaçao and (b) the lagoon at Aruba. SE represents the variability among the 2 to 3 different trials per habitat per life stage different letters above the bars represent significant differences among habitat types (see details in Table S5 in the supplement at www.int-res.com/articles/suppl/m502p229 _supp.pdf), per life stage per bay per island (post-hoc $\chi^{2}$ : $\mathrm{p} \leq 0.05) ;$ surv = survival

potential underlying mechanisms for such a complex life history strategy. Each of the phases identified involved a shift in habitat which appears to be characterized by different trade-offs that likely maximize an individuals' fitness as discussed below.

Settlement in bay environments (Phase 2) seems to be driven by a trade-off between prey availability and predation risk. With respect to predation, Grol et al. (2011) showed that juveniles that settled in an embayment increased their survival from predation, but to the detriment of growth. In this life stage, fishes are diurnally-active planktonic feeders (Ogden \& Ehrlich 1977, Verweij et al. 2006b), predominantly feeding on copepods. Our study shows that food abundance (in terms of pelagic copepods) was higher on reefs than within bay environments. Not only prey standing stock, but likely also prey turnover rate is higher on reefs via continuous replenishment by along-shore oceanic currents. In contrast, consumed prey in shallow and semi-enclosed embayments is only partly (through local productivity) or temporarily (through inflowing tides with oceanic waters) replenished. Thus, by settling just a short distance from the coral reef (i.e. rubble in the bay mouth), fishes increase their survival rate considerably but still benefit from oceanic currents replenishing planktonic prey items. Although a low abundance of copepods was found on rubble, we suggest that fish do benefit from these along-shore oceanic currents. Settlement thus seems highly spatiallydriven for this specific type of seascape where an optimum between predation risk (affecting mortality) and resource acquisition (affecting growth) is the likely underlying mechanism. It should be noted that similar shifts among habitats to minimize the ratio of growth to mortality exist in a wide range of other taxa (Werner 1986, Lima \& Dill 1990, Dahlgren \& Eggleston 2000, Urban 2007, Haywood \& Kenyon 2009).

The apparent ontogenetic habitat shift in our study area from settlement sites in bay mouths to seagrass beds in the bays (Phase 3 ) is likely driven primarily by resource acquisition. Dorenbosch et al. (2009) showed a similar degree of predation risk of early juveniles in bay habitats along a spatial gradient from the mouth of the bay. Therefore, predation risk is unlikely to act as the sole mechanism driving ontogenetic habitat shifts within the bay at this life stage. In this size class (2.0 to $7.9 \mathrm{~cm}$ FL), Haemulon flavolineatum are known to gradually change from pelagic to benthic, and from diurnal to nocturnal feeding (Ogden \& Ehrlich 1977, Helfman et al. 1982, Verweij et al. 2006b). Our data indicated that among bay habitats, Tanaidacea showed highest densities in seagrass beds, in the water column just above the vegetation as well as in the substratum. Furthermore, the open seagrass habitat facilitates the still partially pelagic feeding on copepods compared to the mangrove prop-root habitat (Verweij et al. 2006b). Thus, in this life stage fish benefit from abundant benthic and pelagic food sources on seagrass beds. However, this did not result in significantly higher WL ratios or fat content compared to the rubble habitat.

In Phase 4 (8.0 to $15.9 \mathrm{~cm} \mathrm{TL}$ ), Haemulon flavolineatum in the bay appeared to undergo an ontogenetic habitat shift from seagrass beds to mangroves. This shift is probably driven by the need for optimal refuge from predation. Fishes of this size class are nocturnal feeders and may have outgrown their day-time refuges between seagrass leaves. In this case, resource acquisition is not the underlying mechanism for an ontogenetic habitat shift as fish still feed on seagrass beds at night (Nagelkerken et al. 2000a, 
Nagelkerken \& van der Velde 2004, Verweij et al. 2006b), where food resources are more abundant. Likewise, other studies have shown that large French grunts shelter on patch reefs during the day and migrate to adjacent seagrass beds at night to feed (Ogden \& Ehrlich 1977, Helfman et al. 1982). If sufficient or suitable shelter is provided by seagrass beds, then fishes would presumably not risk moving into mangroves during the day because movement increases mortality risk through increased detection by predators (Crowl 1989). In contrast, the dark, structure-rich mangrove prop-roots form ideal daytime refuges for larger fishes (Laegdsgaard \& Johnson 2001, Cocheret de la Morinière et al. 2004, Verweij et al. 2006a). Verweij et al. (2006a) showed that during the day, largesized $H$. flavolineatum are largely inactive, and show schooling behavior in mangroves. In the absence of predators, fish were observed just in front of mangroves, but moved into mangroves to seek shelter when predators were nearby (Laegdsgaard \& Johnson 2001). Optimal feeding cannot be accomplished in the relatively small fringing mangroves due to (1) low benthic prey densities in the substratum (this study), and (2) individualistic feeding behavior by H. flavolineatum (Ogden \& Ehrlich 1977, Verweij et al. 2006a) which forces fish to select habitats with larger surface areas (such as seagrass beds) to avoid competition. Various studies (Ogden \& Ehrlich 1977, Helfman et al. 1982) have shown that schools of $H$. flavolineatum leave their daytime shelter in groups at dusk, after which they quickly disperse onto seagrass beds in a dendrytic pattern and feed solitarily or in small groups during the night, and return at dawn. In addition, Verweij et al. (2006b) showed that $H$. flavolineatum of the same size class spent a high percent of their time feeding and took more bites per time unit in seagrass beds compared to mangroves. Stable isotope studies further supported that $H$. flavolineatum sheltering in mangroves of Spanish Water Bay during the day depended primarily on seagrass food sources (Nagelkerken \& van der Velde 2004). Hence, diurnally inactive fishes in Phase 4 select optimal mangrove shelter habitat, and migrate at night to seagrass beds harboring the highest densities of favored benthic prey items. WL ratios or fat content did not increase due to the ontogenetic shift from seagrass beds to mangroves, showing no increased benefits in terms of fitness.

Although boulder/notch habitats were not surveyed at Aruba, the shift from mangroves to boulder/notch habitats (Phase 5) was clearly visible on Curaçao. Studies have shown that adult Haemulon flavolineatum are typically associated with hard sub- strata (Kendall et al. 2003, Lindeman \& Richards 2005) and a shift to this habitat is possibly associated with this preference by larger-sized fish (Moura et al. 2011).

The uni-directional movement from bays to coral reefs (Phase 6) coincided with maturation. Fish in bay environments were immature, independent of their size and habitat type occupied; even fishes of 16.0 to $19.9 \mathrm{~cm}$ FL in bays reached only initial stages of maturation, while smaller fishes on reefs had already matured. There is considerable evidence that a large size, fast growth rate, and high lipid content are important criteria for initiation of sexual development (Rowe et al. 1991, Silverstein et al. 1997). Our results corroborate this as on-reef fish achieved higher growth rates and WL ratios, and probably invested their energy (i.e. fat reserves) in gonadal development - as shown by the much lower liver-fat contents and higher gonadal somatic index compared to fish in bay habitats. In addition, fast growing fish may have recruited at earlier ages to the reef in order to complete maturation or to reproduce. Thus, continuing residence within bay habitats does not appear to facilitate maturation, and may in fact inhibit fitness. Reproduction on coral reefs by this pelagic spawner will likely be more successful than in semi-enclosed bays, explaining the need to ultimately move to reef habitats - which is the typical residence habitat for large adults. It is unlikely that predation is the driving factor to shift habitats for this size class, as larger fishes are less vulnerable to predation (Lima \& Dill 1990, Hixon 1991, Dahlgren \& Eggleston 2000).

Most organisms undergo ecological trade-offs during key portions of their life cycle and may therefore inhabit different habitat types during different life stages. This effect also tends to indirectly result in varying levels of connectivity among these habitats. Movement across habitat boundaries can have strong impacts on the dynamics and structure of communities (Polis et al. 1997, Nagelkerken et al. 2012), where changes in one habitat can indirectly affect the community structure in an adjacent, connected habitat (Schreiber \& Rudolf 2008). The current study shows strong linkages among a connected set of different habitat types, which ultimately support population viability of fishes on coral reefs. With the ongoing loss and fragmentation of nearshore coastal ecosystems (Lotze et al. 2006), ontogenetic and diel feeding migrations across habitats may be altered to such a degree that it affects trophic interactions and successful movement of animals among habitats. This may ultimately lead to a decrease in ecosystem 
productivity and resilience (Bellwood et al. 2004, Hughes et al. 2005). Understanding the mechanics of ontogenetic niche shifts is a first critical step towards improved reef fisheries conservation and management, and might lead to enhanced solutions for fisheries declines at larger scales. To sustain healthy fish stocks, it is critical that habitats used in every life stage are protected; effective conservation must therefore account for habitat use over the entire life cycle of the target species - and in particular the younger life stages. This involves the need for preservation of the ecological processes that maintain the connected habitat mosaics required by these species (Nagelkerken et al. 2014).

Acknowledgements. This project was supported by the Netherlands Organization for Scientific Research (NWO) through a VIDI grant to I.N. Additional funding for fieldwork was received from the Department of Agriculture, Husbandry and Fisheries at Aruba (DLVV). We are grateful to the staff and personnel of the Carmabi Institute on Curaçao, M. Lacle from the Technical Inspection Service at Aruba (DTI), the Veterinary Department at Aruba and DLVV for their hospitality and provision of research materials and work/laboratory space (including the provision of a boat, fuel and a boat captain by DLVV at Aruba). We also thank J. de Bie, R. H. N. van der Kant, N. P. Rossen and E. van Engelen for logistic support in the field and assistance in the lab.

\section{LITERATURE CITED}

Acosta CA, Butler BJ (1999) Adaptive strategies that reduce predation on Caribbean spiny lobster postlarvae during onshore transport. Limnol Oceanogr 44:494-501

Aguilar-Perera A, Appeldoorn RS (2008) Spatial distribution of marine fishes along a cross-shelf gradient containing a continuum of mangrove-seagrass-coral reefs off southwestern Puerto Rico. Estuar Coast Shelf Sci 76:378-394

Appeldoorn RS, Aguilar-Perera A, Bouwmeester BLK, Dennis GD and others (2009) Movement of fishes (Grunts: Haemulidae) across the coral reef seascape: a review of scales, patterns and processes. Caribb J Sci 45:304-316

> Aronson RB, Heck KL (1995) Tethering experiments and hypothesis-testing in ecology. Mar Ecol Prog Ser 121: 307-309

> Baker R, Sheaves M (2007) Shallow-water refuge paradigm: conflicting evidence from tethering experiments in a tropical estuary. Mar Ecol Prog Ser 349:13-22

Bathgate R, Maxwell WMC, Evans G (2006) Studies on the effect of supplementing boar semen cryopreservation media with different avian egg yolk types on in vitro post-thaw sperm quality. Reprod Domest Anim 41:68-73

Bellwood DR, Hughes TP, Folke C, Nyström M (2004) Confronting the coral reef crisis. Nature 429:827-833

> Burke JS, Kenworthy WJ, Wood LL (2009) Ontogenetic patterns of concentration indicate lagoon nurseries are essential to common grunts stocks in a Puerto Rican bay. Estuar Coast Shelf Sci 81:533-543

Cocheret de la Morinière E, Pollux BJA, Nagelkerken I, van der Velde G (2003) Diet shifts of Caribbean grunts
(Haemulidae) and snappers (Lutjanidae) and the relation with nursery-to-coral reef migrations. Estuar Coast Shelf Sci 57:1079-1089

> Cocheret de la Morinière E, Nagelkerken I, van der Meij H, van der Velde G (2004) What attracts juvenile coral reef fish to mangroves: habitat complexity or shade? Mar Biol 144:139-145

Crowl TA (1989) Effects of crayfish size, orientation, and movement on the reactive distance of largemouth bass foraging in clear and turbid water. Hydrobiologia 183: $133-140$

Dahlgren CP, Eggleston DB (2000) Ecological processes underlying ontogenetic habitat shifts in a coral reef fish. Ecology 81:2227-2240

> Danilowicz BS, Sale PF (1999) Relative intensity of predation on the French grunt, Haemulon flavolineatum, during diurnal, dusk, and nocturnal periods on a coral reef. Mar Biol 133:337-343

DeVries DR, Frie RV (1996) Determination of age and growth. In: Murphy BR, Willis DW (eds) Fisheries techniques, 2nd edn. American Fisheries Society, Bethesda, MD, p 483-512

> Dorenbosch M, Grol MGG, de Groene A, van der Velde G, Nagelkerken I (2009) Piscivore assemblages and predation pressure affect relative safety of some back-reef habitats for juvenile fish in a Caribbean bay. Mar Ecol Prog Ser 379:181-196

Field A (2006) Discovering statistics using SPSS, 2nd edn. SAGE publications, London

> Grol MGG, Dorenbosch M, Kokkelmans EMG, Nagelkerken I (2008) Mangroves and seagrass beds do not enhance growth of early juveniles of a coral reef fish. Mar Ecol Prog Ser 366:137-146

Grol MGG, Nagelkerken I, Rypel AL, Layman CA (2011) Simple ecological trade-offs give rise to emergent crossecosystem distribution of a coral reef fish. Oecologia 165: 79-88

Haywood MDE, Kenyon RA (2009) Habitat shifts by decapods: an example of connectivity across tropical coastal ecosystems. In: Nagelkerken I (ed) Ecological connectivity among tropical coastal ecosystems. Springer Science \& Business Media, Dordrecht, p 229-269

> Heck KL Jr, Hays G, Orth RJ (2003) Critical evaluation of the nursery role hypothesis for seagrass meadows. Mar Ecol Prog Ser 253:123-136

Helfman GS, Meyer JL, McFarland WN (1982) The ontogeny of twilight migration patterns in grunts (Pisces: Haemulidae). Anim Behav 30:317-326

Hixon MA (1991) Predation as a process structuring coral reef fish communities. In: Sale PF (ed) The ecology of fishes on the coral reef. Academic Press, San Diego, CA, p 475-508

> Hughes TP, Bellwood DR, Folke C, Steneck RS, Wilson J (2005) New paradigms for supporting resilience of marine ecosystems. Trends Ecol Evol 20:380-386

> Johannes RE (1978) Reproductive strategies of coastal marine fishes in the tropics. Environ Biol Fishes 3:65-84

> Jones DL, Walter JF, Brooks EN, Serafy JE (2010) Connectivity through ontogeny: fish population linkages among mangrove and coral reef habitats. Mar Ecol Prog Ser 401: 245-258

> Kaufman L, Ebersole J, Beets J, McIvor CC (1992) A key phase in the recruitment dynamics of coral reef fishes: post-settlement transition. Environ Biol Fishes 34: $109-118$ 
Kendall MS, Christensen JD, Hillis-Starrb Z (2003) Multiscale data used to analyze the spatial distribution of French grunts, Haemulon flavolineatum, relative to hard and soft bottom in a benthic landscape. Environ Biol Fishes 66:19-26

Kimirei IA, Nagelkerken I, Trommelen M, Blankers P and others (2013) What drives ontogenetic niche shifts of fishes in coral reef ecosystems? Ecosystems 16:783-796

Kulmiye AJ, Ntiba MJ, Kisia SM (2002) Some aspects of the reproductive biology of the thumbprint emperor, Lethrinus harak (Forsskål, 1775), in Kenyan coastal waters. Western Indian Ocean J Mar Sci 1:135-144

> Laegdsgaard P, Johnson C (2001) Why do juvenile fish utilise mangrove habitats? J Exp Mar Biol Ecol 257: 229-253

Leis JM (1991) The pelagic stage of reef fishes: the larval biology of coral reef fishes. In: Sale PF (ed) The ecology of fishes on coral reefs. Academic Press, San Diego, CA, p 183-230

Lima SL, Dill LM (1990) Behavioral decisions made under the risk of predation: a review and prospectus. Can J Zool 68:619-640

Lindeman KC (1986) Development of larvae of the French grunt, Haemulon flavolineatum, and comparative development of twelve species of western Atlantic Haemulon (Percoidei, Haemulidae). Bull Mar Sci 39:673-716

Lindeman KC, Richards WJ (2005) Haemulidae: Grunts. In: Richards WJ (ed) Early stages of Atlantic fishes. CRC Press, Boca Raton, FL, p 1597-1645

Lindeman KC, Snyder DB (1999) Nearshore hardbottom fishes of southeast Florida and effects of habitat burial caused by dredging. Fish Bull 97:508-525

> Lotze HK, Lenihan HS, Bourque BJ, Bradbury RH and others (2006) Depletion, degradation, and recovery potential of estuaries and coastal seas. Science 312:1806-1809

- Mateo I, Durbin EG, Appeldoorn RS, Adams AJ and others (2010) Role of mangroves as nurseries for French grunt Haemulon flavolineatum and Schoolmaster Lutjanus apodus assessed by otolith elemental fingerprints. Mar Ecol Prog Ser 402:197-212

McFarland WN (1980) Observations on recruitment in haemulid fishes. Proc Gulf Caribb Fish Inst 32:132-138

McFarland WN, Hillis ZM (1982) Observations on agonistic behavior between members of juvenile French and white grunts - family Haemulidae. Bull Mar Sci 32:255-268

McFarland WN, Brothers EB, Ogden JC, Shulman JM, Bermingham EL, Kothcian-Prentiss NM (1985) Recruitment patterns in young French grunts, Haemulon flavolineatum (family Haemulidae) at St. Croix, Virgin Islands. Fish Bull 83:413-426

> Mora C, Sale PF (2002) Are populations of coral reef fish open or closed? Trends Ecol Evol 17:422-428

> Moura RL, Francini-Filho RB, Chaves EM, Minte-Vera CV, Lindeman KC (2011) Use of riverine through reef habitat systems by dog snapper (Lutjanus jocu) in eastern Brazil. Estuar Coast Shelf Sci 95:274-278

Nagelkerken I (2007) Are non-estuarine mangroves connected to coral reefs through fish migration? Bull Mar Sci 80:595-607

Nagelkerken I (2009) Evaluation of nursery function of mangroves and seagrass beds for tropical decapods and reef fishes: patterns and underlying mechanisms. In: Nagelkerken I (ed) Ecological connectivity among tropical coastal ecosystems. Springer Science \& Business Media, Dordrecht, p 357-399
Nagelkerken I, van der Velde G (2004) Relative importance of interlinked mangroves and seagrass beds as feeding habitats for juvenile reef fish on a Caribbean island. Mar Ecol Prog Ser 274:153-159

> Nagelkerken I, Dorenbosch M, Verberk WCEP, Cocheret de la Morinière E, van der Velde G (2000a) Day-night shifts of fishes between shallow-water biotopes of a Caribbean bay, with emphasis on the nocturnal feeding of Haemulidae and Lutjanidae. Mar Ecol Prog Ser 194:55-64

> Nagelkerken I, Dorenbosch M, Verberk WCEP, Cocheret de la Morinière E, van der Velde G (2000b) Importance of shallow-water biotopes of a Caribbean bay for juvenile coral reef fishes: patterns in biotope association, community structure and spatial distribution. Mar Ecol Prog Ser 202:175-192

Nagelkerken I, van der Velde G, Gorissen MW, Meijer GJ, van 't Hof T, den Hartog C (2000c) Importance of mangroves, seagrass beds and the shallow coral reef as a nursery for important coral reef fishes, using a visual census technique. Estuar Coast Shelf Sci 51:31-44

Nagelkerken I, Grol MGG, Mumby PJ (2012) Effects of marine reserves versus nursery habitat availability on structure of reef fish communities. PLoS ONE 7:e36906

Nagelkerken I, Sheaves M, Baker R, Connolly RM (2014) The seascape nursery: a novel spatial approach to identify and manage nurseries for coastal marine fauna. Fish Fish, doi:10.1111/faf.12057

Nemeth RS (2009) Dynamics of reef fish and decapod crustacean spawning aggregations: underlying mechanisms, habitat linkages, and trophic interactions. In: Nagelkerken I (ed) Ecological connectivity among tropical coastal ecosystems. Springer Science \& Business Media, Dordrecht, p 73-134

Ntiba MJ, Jaccarini V (1990) Gonad maturation and spawning times of Siganus sutor off the Kenya coast: evidence for definite spawning seasons in a tropical fish. J Fish Biol 37:315-325

> Ogden JC, Ehrlich PR (1977) The behaviour of heterotypic resting schools of juvenile grunts (Pomadasyidae). Mar Biol 42:273-280

Parrish JD (1989) Fish communities of interacting shallowwater habitats in tropical oceanic regions. Mar Ecol Prog Ser 58:143-160

Peterson CH, Black R (1994) An experimentalist's challenge: when artifacts of intervention interact with treatments. Mar Ecol Prog Ser 111:289-297

Polis GA, Anderson WB, Holt RD (1997) Toward an integration of landscape and food web ecology: the dynamics of spatially subsidized food webs. Annu Rev Ecol Syst 28: 289-316

Pollux BJA, Verberk WCEP, Dorenbosch M, de la Morinière E, Nagelkerken I, van der Velde G (2007) Habitat selection during settlement of three Caribbean coral reef fishes: indications for directed settlement to seagrass beds and mangroves. Limnol Oceanogr 52:903-907

Rooker JR, Dennis GD (1991) Diel, lunar and seasonal changes in a mangrove fish assemblage off southwestern Puerto Rico. Bull Mar Sci 49:684-694

Roughgarden J, Gaines S, Possingham H (1988) Recruitment dynamics in complex life cycles. Science 241: 1460-1466

Rowe DK, Thorpe JE, Shanks AM (1991) Role of fat stores in the maturation of male Atlantic salmon (Salmo salar) parr. Can J Fish Aquat Sci 48:405-413

- Rypel AL (2011) River impoundment and sunfish growth. 
River Res Appl 27:580-590

Schäfer ML, Lundkvist E, Landin J, Persson TZ, Lundström JO (2006) Influence of landscape structure on mosquitos (Diptera: Culicidae) and dytiscids (Coleoptera: Dytiscidae) at five spatial scales in Swedish wetlands. Wetlands 26:57-68

Schreiber S, Rudolf VHW (2008) Crossing habitat boundaries: coupling dynamics of ecosystems through complex life cycles. Ecol Lett 11:576-587

Shulman MJ (1985) Recruitment of coral reef fishes: effects of distribution of predators and shelter. Ecology 66: 1056-1066

Shulman MJ, Ogden JC (1987) What controls tropical reef fish populations: recruitment or benthic mortality? An example in the Caribbean reef fish Haemulon flavolineatum. Mar Ecol Prog Ser 39:233-242

Silverstein JT, Shimma H, Ogata H (1997) Early maturity in amago salmon (Oncorhynchus masu ishikawai): an association with energy storage. Can J Fish Aquat Sci 54: 444-451

Stephens DW, Krebs JR (1986) Foraging theory. Princeton University Press, Princeton, NJ

Sutherland WJ (1996) From individual behaviour to population ecology. Oxford University Press, New York, NY

Urban MC (2007) Risky prey behavior evolves in risky habi-

Editorial responsibility: Kenneth Heck Jr., Dauphin Island, Alabama, USA tats. Proc Natl Acad Sci USA 104:14377-14382

> Verweij MC, Nagelkerken I (2007) Short and long-term movement and site fidelity of juvenile Haemulidae in back-reef habitats of a Caribbean embayment. Hydrobiologia 592:257-270

Verweij MC, Nagelkerken I, de Graaf D, Peeters M, Bakker EJ, van der Velde G (2006a) Structure, food and shade attract juvenile coral reef fish to mangrove and seagrass habitats: a field experiment. Mar Ecol Prog Ser 306: 257-268

Verweij MC, Nagelkerken I, Wartenbergh SLJ, Pen LR, van der Velde G (2006b) Caribbean mangroves and seagrass beds as diurnal feeding habitats for juvenile French grunts, Haemulon flavolineatum. Mar Biol 149:1291-1299

> Verweij MC, Nagelkerken I, Hans I, Ruseler SM, Mason PRD (2008) Seagrass nurseries contribute to coral reef fish populations. Limnol Oceanogr 53:1540-1547

> Werner EE (1986) Amphibian metamorphosis: growth rate, predation risk, and the optimal size at transformation. Am Nat 128:319-341

Werner EE, Gilliam JF (1984) The ontogenetic niche and species interactions in size-structured populations. Annu Rev Ecol Syst 15:393-425

Zollner PA, Lima SL (2005) Behavioral tradeoffs when dispersing across a patchy landscape. Oikos 108:219-230

Submitted: March 27, 2013; Accepted: December 4, 2013 Proofs received from author(s): March 18, 2014 